\title{
Efektifitas Penegakan Hukum Terhadap Perilaku "Ngelem" Pada Anak Remaja Sebagai Pelaku Sekaligus Korban (Self Victimizing) Di Kawasan Kampung Zombie Kota Samarinda
}

\author{
Dinny Wirawan Pratiwie, Ayu Linanda \\ dinipratiwie@gmail.com, ayulinanda@uwgm.ac.id, \\ Fakultas Hukum \\ Program Studi Ilmu Hukum \\ Universitas Widya Gama Mahakam Samarinda
}

\begin{abstract}
ABSTRAK
Keberadaan salah satu kawasan kampung di wilayah Kota Samarinda yang menjadi pusat atau markas dari anak remaja untuk melakukan aktivitas menghisap lem, yang sebelumnya dikenal dengan istilah Kampung Zombie, terletak di Kelurahan Mangkupalas, Kecamatan Samarinda Seberang Kota Samarinda, menjadi sebuah fenomena sosial yang cukup memprihatinkan. Dalam menyikapinya, diperlukan korelasi yang bersinergi dengan semua stakeholder dalam rangka mewujudkan efektifitas penegakan hukum terhadap perilaku ngelem pada anak remaja melalui upaya-upaya penegakan hukum terhadap perilaku "ngelem" yang menjadi tolak ukur keberhasilan penegakan hukum pada perilaku anak remaja "ngelem" sebagai pelaku sekaligus korban (self victimizing) khususnya di Kawasan Kampung Zombie, Kota Samarinda.
\end{abstract}

Kata kunci: Efektifitas, Ngelem, Selfvictimizing, Kampung Zombie.

\section{ABSTRACT}

The existence of one of the Kampong in the region of Samarinda central or headquarters of the older children to do activities suck glue, which was previously known as the Hometown of zombies, located in the village Mangkupalas, district Samarinda Seberang, Samarinda City became a social phenomenon that is quite a concern. In menyikapinya, the required correlation synergize with all stakeholders in order to realize the effectiveness of law enforcement against the behavior of ngelem in young adolescents through law enforcement efforts against the behavior of the "ngelem" benchmark the success of law enforcement on the behavior of older children "ngelem" as the offender while the victim (self victimizing) especially in Kampong zombies, Samarinda.

Keywords: Effectiveness, Ngelem, Selfvictimizing, Kampung Zombies. 


\section{PENDAHULUAN}

\section{A. Latar Belakang}

Adanya idiom mengenai "anak sebagai generasi penerus cita-cita perjuangan bangsa" kini hanya menjadi anekdot, kenyataannya moral etika pada anak bangsa Indonesia telah terkikis di makan zaman yang berdampak pada hilangnya rasa nasionalisme pada bangsa. Kategori anak remaja yang seharusnya memiliki rasa nasionalisme guna membangun bangsa terletak pada kalangan anak remaja yang memiliki usia produktif yaitu usia bersekolah. Hal ini kemudian dikuatkan dengan berbagai artikel yang menyatakan anak remaja memiliki titik krusial dalam menentukan pembangunan suatu bangsa. Hilangnya rasa nasionalisme pada anak disebabkan keberadaan arus globalisasi yang membawa budaya luar yang tidak sesuai dengan moral etika bangsa Indonesia sehingga menghilangkan nilai etika atau tata krama yang di miliki oleh anak remaja saat ini dan memberikan dampak negatif pada pola perilaku anak remaja itu sendiri, dimana anak mampu melakukan perbuatan-perbuatan menyimpang bahkan dapat mengarah pada tindakan kriminal. Salah satu perilaku menyimpang yang fenomena saat ini ialah "ngelem". Istilah "ngelem" secara harfiah berarti menghirup lem, atau sering disebut dengan inhalan.

Secara sosial, perilaku ngelem atau inhalan yang dilakukan anak remaja termasuk kategori kenakalan remaja atau juvenile delinquency, yang disebabkan oleh pengaruh pergaulan berteman, hingga pengabaian sosial baik dalam keluarga maupun di lingkungan sekitar, akibatnya anak remaja mengalami perubahan emosional yang tidak jarang membawa kepada halusinasi, dan perilaku negatif, seperti berbicara kotor, mencuri, dan berkelahi. Selain itu, dampak kesehatan bagi anak remaja yang menghisap ngelem juga sangat membahayakan karena dapat menyebabkan kematian mendadak pada si konsumennya.

Ironinya, pelaku "ngelem" dikalangan anak remaja semakin diminati. Setiap tahunnya jumlah perilaku "ngelem" pada anak remaja terus bertambah di setiap daerah di Indonesia. Salah satunya, Kota
Samarinda, sebagai ibu kota provinsi Kalimantan Timur dengan luas wilayah 718 $\mathrm{km} 2$, dan jumlah populasi penduduk sekitar 812.597 jiwa, maka Kota Samarinda berpotensi memiliki hampir sebagian besar anak remaja kecanduan "ngelem".

Hal ini tampak dari jumlah kasus anak remaja "ngelem" yang terus meningkat di Kota Samarinda cukup memprihatinkan. Sedangkan dari kategori perilaku "ngelem" anak remaja di Kota Samarinda lebih dominan dilakukan oleh anak jalanan dibandingkan anak sekolah. Yang menarik adalah ketika salah satu kawasan di Kota Samarinda menjadi pusat atau markas dari anak remaja untuk melakukan aktivitas menghisap lem yang dilakukan terus menerus sehingga berdampak pada kesehatannya, dimana sebagian besar anak remaja yang tinggal di kawasan tersebut menjadi linglung, kehilangan kesadaran, saraf yang terganggu hingga jika mereka berjalan terlihat seperti zombie. Oleh karena itulah kawasan tersebut digelari istilah kawasan kampung zombie.

Kawasan kampung zombie, Kota Samarinda terletak di Kelurahan Mangkupalas, Kecamatan Samarinda Seberang, Kota Samarinda. Hampir sebagian besar anak remaja di kawasan kampung zombie kecanduan ngelem, namun tak jarang banyak anak remaja dari luar kampung zombie juga sering melakukan aktivitas menghisap lem di daerah kampung zombie tersebut, sehingga kawasan kampung zombie menjadi kawasan yang cukup memprihatinkan. Bahkan, anak remaja yang kecanduan ngelemnya telah melebihi dosis dapat melakukan tindakan kriminal seperti meminum minuman keras, melakukan seks bebas, dan tak jarang melakukan penganiayaan hingga mampu membunuh seseorang. Oleh karena itulah Pemerintah Kota Samarinda berupaya menanggulangi fenomena perilaku "ngelem" pada anak remaja mulai dari sosialisasi bahaya "ngelem" dari beberapa stakeholder terkait, salah satunya melakukan operasi gabungan oleh Satpol PP dalam mengamankan para anak remaja yang menghisap lem. Namun, tak mampu menekan jumlah angka anak remaja yang menghisap lem di Kota Samarinda 
khususnya kawasan Kampung Zombie, Kota Samarinda.

Ketidak mampuan itulah yang pada akhirnya membuat Pemerintah Provinsi Kalimantan Timur segera mengesahkan Peraturan Daerah Provinsi Kalimantan Timur Nomor 05 Tahun 2015 tentang Pencegahan Penyalahgunaan inhalan. Hal ini merupakan salah satu bagian dari upaya Pemerintah Provinsi Kalimantan Timur dalam mengurangi jumlah anak remaja yang kecanduan "ngelem", khususnya di Kota Samarinda yang memiliki salah satu daerah sempurna yang digunakan sebagai tempat pilihan bagi anak remaja pengguna inhalan, yaitu Kawasan Kampung Zombie Kota Samarinda.

Menelaah ketentuan norma dalam Peraturan Daerah Provinsi Kalimantan Timur Nomor 05 Tahun 2015 tentang Pencegahan Penyalahgunaan Inhalan ini memang sudah cukup baik, hanya sasaran dari Peraturan Daerah Provinsi Kalimantan Timur Nomor 05 Tahun 2015 tentang Pencegahan Penyalahgunaan Inhalan ini kurang tepat sasaran, dimana Peraturan Daerah Provinsi Kalimantan Timur Nomor 05 Tahun 2015 tentang Pencegahan Penyalahgunaan Inhalan ini lebih menitikberatkan pada produsen atau pelaku usaha yang dapat diberikan sanksi, namun kepada anak remaja yang melakukan perbuatan menghisap lem hanya melakukan pemeriksaan lebih lanjut untuk selanjutnya diberikan fasilitas rehabilitasi dalam rangka menghilangkan kecanduan dalam menghisap lem sehingga tidak ada efek jera yang dirasakan oleh anak remaja ini.

Dalam memberikan efek jera berupa sanksi kepada anak remaja juga patut diperhatikan bahwa anak remaja ini juga merupakan korban dari kejahatan yang dilakukannya sendiri (SelfVictimizing) sehingga dalam memberikan sanksi kepada anak remaja ini haruslah hati-hati dan tepat sasaran, terlebih lagi belum ada payung hukum yang mengatur mengenai perilaku "ngelem" pada anak remaja yang dimana tindakan instansi terkait hanya bergantung pada peraturan daerah setempat serta surat edaran dari pemimpin daerah tersebut, seperti yang terjadi di Kota Samarinda dalam rangka mencegah perilaku "ngelem" anak remaja,
Walikota Samarinda telah mengeluarkan surat edaran tentang larangan penjualan lem untuk mendukung efektifnya penegakan hukum Peraturan Daerah Provinsi Kalimantan Timur Nomor 05 Tahun 2015 tentang Pencegahan Penyalahgunaan Inhalan di wilayah Kota Samarinda.

Namun, efektifkah Peraturan Daerah Provinsi Kalimantan Timur Nomor 05 Tahun 2015 tentang Pencegahan Penyalahgunaan Inhalan ini dalam mencegah perilaku "ngelem" pada anak remaja? Ternyata tidak. Kurang lebih dua tahun di terapkan di masyarakat khususnya di Kota Samarinda saja, jumlah angka anak remaja yang ngelem tidak berkurang, bahkan mereka mampu menjadikan satu kawasan sebagai markas mereka untuk melakukan aktivitas menghisap lem yaitu Kampung Zombie, Kelurahan Mangkupalas, Kecamatan Samarinda Seberang Kota Samarinda.

Dalam hal ini Pemerintah Kota Samarinda seolah-olah tak mampu berbuat banyak, bahkan sekalipun mereka di tangkap, kemudian, di bina, dan di pulangkan, lalu kembali ke jalanan, mereka akan tetap melakukan perbuatan yang sama menghisap zat inhalan itu berulangkali bahkan kali ini lebih hati-hati agar tidak ketahuan. Ketidak efektifan selanjutnya ialah larangan penjualan lem oleh pelaku usaha yang bila dilanggar maka pelaku usaha dapat diberikan sanksi berupa sanksi administratif yang tidak berjalan tepat sasaran, pada kenyataannya anak-anak remaja tersebut masih sangat mudah mendapatkan beraneka merek lem.

Permasalahan inilah yang

melatarbelakangi ketertarikan peneliti untuk melakukan studi penelitian lebih lanjut secara jelas, lugas, dan tegas mengenai "Efektifitas Penegakan Hukum Terhadap Perilaku "Ngelem" Pada Anak Remaja Sebagai Pelaku Sekaligus Korban (Self Victimizing) di Kawasan Kampung Zombie Kota Samarinda". 


\section{B. Permasalahan}

Berdasarkan uraian dalam latar belakang, maka yang menjadi rumusan masalah dalam penulisan ini adalah sebagai berikut :

1. Apakah penegakan hukum terhadap perilaku "ngelem" pada anak remaja sebagai pelaku sekaligus korban (self victimizing) mampu mengurangi jumlah anak remaja yang melakukan aktivitas menghisap lem di kawasan Kampung Zombie Kota Samarinda?

2. Bagaimana efektifitas penegakan hukum terhadap perilaku "ngelem" pada anak remaja sebagai pelaku sekaligus korban (self victimizing) di kawasan Kampung Zombie Kota Samarinda.

\section{Tujuan dan Manfaat Penelitian}

Adapun Tujuan Penelitian ini adalah untuk mengidentifikasi penegakan hukum terhadap perilaku "ngelem" pada anak remaja sebagai pelaku sekaligus korban (self victimizing) mampu mengurangi jumlah anak remaja yang melakukan aktivitas menghisap lem di kawasan kampung zombie kota samarinda.

Untuk menganalisa efektifitas penegakan hukum terhadap perilaku "ngelem" pada anak remaja sebagai pelaku sekaligus korban (self victimizing) di kawasan kampung zombie kota samarinda.

Adapun penelitian ini diharapkan bermanfaat baik secara akademisi yaitu Sebagai Bahan Kajian Dan Menambah Khasanah Didalam Perkembangan Ilmu Hukum Bagi Akademisi. Dan bagi Pemerintah diharapkan penelitian ini bermanfaat sebagai bahan masukan bagi Pemerintah Dalam Menciptakan Rekayasa Sosial Terhadap Lingkungan Anak Remaja Sehingga Membuat Kebijakan Suatu Produk Hukum Dalam Rangka Mencegah Perilaku "Ngelem" Pada Anak Remaja Di Kawasan Kampung Zombie Kota Samarinda

\section{METODE PENELITIAN}

Dalam penelitian ini menggunakan penelitian yuridis empiris. Sehingga Metode Pengumbulan Data dalam Penelitian ini menggunakan Data Primer dan Data Sekunder.
Data primer diperoleh dari para stakeholder terkait dengan permasalahan yang diteliti dengan metode wawancara yaitu Dinas Sosial Provinsi Kalimantan Timur, Badan Narkotika Nasional Kota Samarinda, Institusi Program Wajib Lapor (IPWL) Yayasan Laras, Lurah Kelurahan Mangkupalas Samarinda Seberang, serta seorang anak bernama Dara Munawaroh yang tinggal di kawasan Kampung Zombie, Kelurahan Mangkupalas, Kecamatan Samarinda Seberang, Kota Samarinda, Kalimantan Timur.

Data sekunder yang digunakan dalam penelitian ini diperoleh dari bahan hukum primer dan bahan hukum sekunder serta bahan hukum tersier ${ }^{1}$ Bahan hukum primer terdiri dari Undang-Undang Dasar 1945, UndangUndang Nomor 11 Tahun 2009 tentang Kesehjateraan Sosial, Peraturan Pemerintah Nomor 25 Tahun 2011 tentang Pelaksanaan Wajib Lapor Pecandu Narkotika, Keputusan Presiden Republik Indonesia Nomor 11 Tahun 2016 Tentang Program Penyusunan Peraturan Presiden Tahun 2016 mengenai Rancangan Peraturan Presiden tentang Optimalisasi Penanggulangan Penyalahgunaan Narkotika, dan Peraturan Daerah Provinsi Kalimantan Timur Nomor 05 Tahun 2015 tentang Pencegahan Penyalahgunaan Inhalan. Bahan hukum sekunder berupa Buku tentang Hukum Pertambangan, naskah akademik, hasil penelitian, tesis, jurnal, internet dan surat kabar. Bahan hukum tersier berupa kamus hukum, dan kamus besar bahasa Indonesia.

Teknik Pengumpan Data yang digunakan dalam Penelitian ini yaitu menggunakan teknik penentuan subjek penelitian dengan menggunakan Teknik Purposive Sampling. Dimana teknik ini digunakan sebagai pertimbangan tertentu. Teknik pengumpulan data yaang digunakan dalam penelitian ini adalah observasi, wawancara mendalam dan dokumentasi.

Dalam Penelitian ini analisis data yang dilakukan berupa analisis data secara kualitatif yang bersifat deskriptif.

\footnotetext{
${ }^{1}$ Amiruddin dan Zainal Asikin, 2004, Pengantar Metode Penelitian Hukum, Jakarta, PT. Raja Grafindo Persada., Hlm., 30-31.
} 


\section{PEMBAHASAN}

\section{A. Penegakan Hukum Terhadap Perilaku "Ngelem" Pada Anak Remaja Sebagai Pelaku Sekaligus Korban (Self Victimizing) Mampu Mengurangi Jumlah Anak Remaja Yang Melakukan Aktivitas Menghisap Lem Di Kawasan Kampung Zombie Kota Samarinda}

Bahayanya perilaku inhalen (ngelem) yang dilakukan oleh anak remaja telah masuk kategori penyalahgunaan NAPZA (Narkotika, Psikotropika, dan Zat Adiktif). Hal ini disebabkan karena inhalen (ngelem) termasuk kategori zat adiktif lainnya yang dapat menimbulkan ketergantungan dan mempengaruhi kinerja otak untuk jangka panjang.

Ironinya, perilaku menyimpang ini telah menjadi tren dikalangan para remaja yang telah mengarah pada fenomena sosial yang cukup memprihatinkan di tengah-tengah masyarakat. Hal ini terlihat dengan semakin banyaknya peminat pengguna inhalen (ngelem) oleh anak remaja di setiap wilayah di Indonesia. Salah satu wilayah yang merasakan dampak dari meningkatnya kuantitas perilaku menyimpang inhalen (ngelem) dikalangan para remaja adalah kawasan Kampung Zombie, yang terletak di Kelurahan Mangkupalas, Samarinda Seberang, Kota Samarinda.

Jargon ini diberikan pada kawasan tersebut karena melekatnya aktivitas yang cukup memprihatinkan dan dilakukan berulang-ulang oleh anak remaja dalam melakukan perilaku menyimpang inhalen (ngelem) tersebut. Aktivitas kegiatan inhalen (ngelem) tersebut sebagian besar tersebut dilakukan di kawasan sekitar Kelurahan Mangkupalas, Samarinda Seberang, Kota Samarinda, karena tempatnya yang cukup strategis untuk melakukan kegiatan inhalen (ngelem) oleh anak remaja pengguna inhalen (ngelem), sehingga tempat tersebut dijadikan sebagai markas oleh anak remaja pengguna inhalen (ngelem).

Dipilihnya kawasan tersebut sebagai markas oleh anak remaja pengguna inhalen (ngelem) karena kawasan tersebut memiliki bukit yang dapat menjadi tempat persembunyian oleh anak remaja pengguna inhalen (ngelem) untuk melakukan semua kegiatan inhalan (ngelem) tanpa dapat dilihat, atau diusir, bahkan diganggu oleh masyarakat yang tinggal disekitar kawasan kampung tersebut hingga aparat penegak hukum. Oleh karena itu, atas keprihatinan yang cukup mengkhawatirkan itulah, Pemerintah Daerah setempat bekerjasama dengan masyarakat, dan stakeholder lainnya bersama-sama menangani fenomena sosial tersebut. Sasaran utama dalam penanganan ini ialah anak remaja, sehingga tidak mudah bagi stakeholder yang terlibat dalam menangani perilaku menyimpang ini, mengingat kedudukan anak remaja yang menjadi pengguna aktif inhalen (ngelem) ini bukan hanya pelaku namun juga korban (self victimizing) sehingga diperlukan win-win solution yang diharapkan mampu menekan jumlah pengguna anak remaja sebagai pengguna aktif inhalan (ngelem).

Berdasarkan fakta tersebut, perlu dilakukan penanganan yang cukup hati-hati dengan menciptakan sebuah rekayasa sosial berupa penegakan hukum terhadap perilaku menyimpang inhalan (ngelem) pada anak remaja yang juga merupakan pelaku sekaligus korban (self victimizing). Keberadaan penegakan hukum ini diharapkan menjadi winwin solution bagi semua kalangan di masyarakt agar penanganan terhadap perilaku menyimpang inhalen (ngelem) menjadi lebih tepat sasaran.

Ada beberapa upaya penegakan hukum yang sudah dibuat oleh Pemerintah Daerah bekerjasama dengan stakeholder terkait dalam menyikapi fenomena kawasan Kampung Zombie, Kelurahan Mangkupalas, Samarinda Seberang Kota Samarinda tersebut. Secara garis besar upaya-upaya penegakan hukum tersebut tertuang dalam Peraturan Daerah Provinsi Kalimantan Timur Nomor 05 Tahun 2015 Tentang Pencegahan Penyalahgunaan Inhalan.

Oleh karenanya, keberadaan Peraturan Daerah Provinsi Kalimantan Timur Nomor 05 Tahun 2015 Tentang Pencegahan Penyalahgunaan Inhalan merupakan acuan 
bagi aparat penegak hukum dan stakeholder terkait dalam menegakan hukum terhadap perilaku inhalen (ngelem) pada anak remaja di kawasan Kampung Zombie, Kelurahan Mangkupalas, Samarinda Seberang, Kota Samarinda.

Dalam hal ini yang termasuk dalam aparat penegak hukum tersebut ialah lembagalembaga yang bersentuhan langsung maupun tidak langsung dalam penanganan perilaku inhalen (ngelem) pada anak remaja, diantaranya ialah Pemerintah Kota Samarinda (diwakili Kecamatan, dan Kelurahan), Dinas Sosial Provinsi, dan Kota , Badan Narkotika Nasional (BNN), dan Institusi Program Wajib Lapor (IPWL), serta Kepolisian Daerah setempat.

Selain itu, sebagian besar bentuk-bentuk penegakan hukum yang diatur sebagai norma dalam Peraturan Daerah Provinsi Kalimantan Timur Nomor 05 Tahun 2015 Tentang Pencegahan Penyalahgunaan Inhalan hanya sebatas sebagai bentuk pengarahan, peneguran, atau pemulihan semata, diantaranya berupa pencegahan, pembinaan dan pengawasan, advokasi, dan rehabilitasi, namun dalam hal penindakan yang memberikan efek jera kepada anak remaja sebagai pengguna aktif inhalen (ngelem) seperti penjatuhan sanksi berupa sanksi pidana, sanksi administrartif, maupun sanksi yg bersifat denda belum ada.

Menurut penulis tidak adanya norma sanksi yang diberikan dalam Peraturan Daerah Provinsi Kalimantan Timur Nomor 05 Tahun 2015 Tentang Pencegahan Penyalahgunaan Inhalan sebagai efek jera dikarenakan mempertimbangkan kedudukan anak remaja pengguna inhalen (ngelem) sebagai self victimizing.

Artinya kedudukan anak remaja pengguna inhalen (ngelem) disini bukan hanya sebagai pelaku namun juga kedudukannya sebagai korban, sehingga tidak mungkin memberikan efek jera murni yang menjadikan anak remaja sebagai seorang pelaku, mengingat kedudukan anak remaja tersebut juga merupakan korban (victim) yang menyulitkan bagi penegakan hukum untuk dapat memberikan efek jera murni kepada anak remaja sebagai pengguna aktif inhalen (ngelem).
Oleh karena itu, penegakan hukum yang diberikan dalam hal ini lebih banyak mengenai pemulihan dibandingkan memberikan efek jera. Orientasi mengarah kepada pembinaan ini dianggap lebih baik dibandingkan memberikan efek jera kepada anak remaja sebagai pelaku sekaligus korban (self victimizing).

Salah satu bentuk pembinaan yang tercakup dalam Peraturan Daerah Provinsi Kalimantan Timur Nomor 05 Tahun 2015 Tentang Pencegahan Penyalahgunaan Inhalan dan dianggap mampu menangani ketimpangan sosial yang disebabkan perilaku inhalan (ngelem) ini adalah rehabilitasi. Arahnya bukan kepada mencegah perilaku menyimpang pengguna inhalen (ngelem) oleh anak remaja, sehingga fenomena sosial ini tidak lagi tumbuh subur di masyarakat, namun lebih kepada pemulihan keadaan atau menyembuhkan anak remaja sebagai pengguna aktif inhalen (ngelem).

Memahami hal tersebut, maka orientasi penegakan hukum terhadap perilaku inhalen (ngelem) di kawasan Kampung Zombie, Kelurahan Mangkupalas, Samarinda Seberang Kota Samarinda juga berlandaskan pada Peraturan Daerah Provinsi Kalimantan Timur Nomor 05 Tahun 2015 Tentang Pencegahan Penyalahgunaan Inhalan, sehingga arah dari penindakan dalam penegakan hukum ini lebih kepada pemulihan keadaan ketimbang memberikan efek jera kepada anak yang juga menjadi pelaku dan korban sekaligus.

Oleh karenanya, selama observasi penulis, menemukan win-win solution yang diberikan oleh aparat penegak hukum dalam melaksanakan penegakan hukum terhadap perilaku menyimpang inhalen (ngelem) di kawasan Kampung Zombie, Kelurahan Mangkupalas, Samarinda Seberang Kota Samarinda, meskipun beraneka ragam namun tetap satu kontekstual yaitu berpegangan pada Peraturan Daerah Provinsi Kalimantan Timur Nomor 05 Tahun 2015 Tentang Pencegahan Penyalahgunaan Inhalan.

Badan Narkotika Nasional Kota Samarinda adalah aparat penegak hukum yang pertama kali menegaskan hal tersebut, bahwa apabila ada ditemukannya indikasi anak remaja yang menjadi pengguna inhalen (ngelem) aktif di kawasan Kampung Zombie, Kelurahan Mangkupalas, Samarinda Seberang Kota 
Samarinda merujuk pada Peraturan Daerah Provinsi Kalimantan Timur Nomor 05 Tahun 2015 Tentang Pencegahan Penyalahgunaan Inhalan dan sejumlah aturan terkait mengenai NAPZA (Narkotika, Psikotropika, dan Zat Adiktif), maka akan dilakukan rehabilitasi.

Rehabilitasi ini merupakan bentuk penegakan hukum yang diharapkan mampu menekan jumlah anak remaja yang menjadi pengguna inhalan (ngelem) aktif menjadi pulih dalam jangka panjang agar tidak menjadi pecandu zat adiktif inhalen (ngelem) kembali. Program rehabilitasi bukan hanya satu-satunya dilakukan oleh Badan Narkotika Nasional Kota Samarinda, aparat penegak hukum lainnya seperti Dinas Sosial Provinsi Kalimantan Timur yang bekerja sama dengan Institusi Program Wajib Lapor (IPWL) dalam hal ini di Kalimantan Timur diwakili oleh Yayasan Laras Kalimantan Timur, merupakan aparat penegak hukum lainnya yang juga melaksanakan pembinaan dengan mencanangkan program Rehabilitasi terhadap anak remaja yang menjadi pengguna inhalen (ngelem) aktif.

Hal ini menegaskan bahwa dalam hal menegakkan hukum apabila ditemukan anak remaja yang menjadi pengguna inhalen (ngelem) aktif di kawasan Kampung Zombie, Kelurahan Mangkupalas, Samarinda Seberang, Kota Samarinda, Dinas Sosial Provinsi Kalimantan Timur yang bekerja sama dengan Institusi Program Wajib Lapor (IPWL) Yayasan Laras Kalimantan Timur, juga mengacu pada Peraturan Daerah Provinsi Kalimantan Timur Nomor 05 Tahun 2015 Tentang Pencegahan Penyalahgunaan Inhalan.

Hal ini terlihat pada hasil observasi yang penulis temukan bahwa ada beberapa laporan terkait indikasi anak remaja yang menjadi pengguna inhalen (ngelem) di kawasan Kampung Zombie, Kelurahan Mangkupalas, Samarinda Seberang, Kota Samarinda, serta tindakan-tindakan yang segera di ambil oleh Dinas Sosial Provinsi Kalimantan Timur yang bekerja sama dengan Institusi Program Wajib Lapor (IPWL) Yayasan Laras Kalimantan Timur dalam menindaklanjuti anak remaja yang menjadi pengguna inhalen (ngelem) di kawasan Kampung Zombie, Kelurahan Mangkupalas, Samarinda Seberang, Kota Samarinda.
Secara keseluruhan tindakan yang diambil oleh Institusi Program Wajib Lapor (IPWL) Yayasan Laras Kalimantan Timur sebagai perwakilan Dinas Sosial Provinsi Kalimantan Timur lebih mengarah kepada pembinaan berupa rehabilitasi yang bertujuan untuk pemulihan kepada anak remaja yang menjadi pengguna inhalen (ngelem) di kawasan Kampung Zombie, Kelurahan Mangkupalas, Samarinda Seberang, Kota Samarinda.

Bentuk upaya penegakan hukum tersebut dianggap mampu meng-cover atau perilaku menyimpang penggunaan inhalen (ngelem) pada anak remaja khususnya di kawasan Kampung Zombie, Kelurahan Mangkupalas, Samarinda Seberang, Kota Samarinda atau dapat dinyatakan telah terealisasi dengan baik apabila tujuannya sebagai pemulihan keadaan terhadap jiwa fisik dan psikis anak remaja yang sudah menjadi pengguna inhalen (ngelem) aktif yang berkedudukan sebagai korban bukan hanya sebagai pelaku, namun apabila yang diharapkan adalah meminimalisir kuantitas perilaku menyimpang pengguna inhalen (ngelem) aktif maka upaya penegakan hukum yang lebih berorientasi kepada pembinaan dalam Peraturan Daerah Provinsi Kalimantan Timur Nomor 05 Tahun 2015 Tentang Pencegahan Penyalahgunaan Inhalan terhadap perilaku meyimpang inhalen (ngelem) khususnya di kawasan Kampung Zombie, Kelurahan Mangkupalas, Samarinda Seberang, Kota Samarinda belum mampu menjawab problematika tersebut.

Disisi lain, ada upaya lainnya diluar dari penegakan hukum dalam meminimalisir kuantitas perilaku meyimpang inhalen (ngelem) di kawasan Kampung Zombie, Kelurahan Mangkupalas, Samarinda Seberang, Kota Samarinda yang dilakukan oleh Pemerintah Kota Samarinda dalam hal ini diwakili oleh Kecamatan dan Kelurahan setempat.

Upaya lain tersebut merupakan sebuah strategi yang cukup unik sebagai bentuk kepedulian Pemerintah Kota Samarinda dalam menyikapi fenomena sosial yang terjadi di kawasan tersebut. Hal ini terlihat selama observasi penulis menemukan fakta bahwa jargon kawasan Kampung Zombie, Kelurahan 
Mangkupalas, Samarinda Seberang, Kota Samarinda sudah tidak lagi melekat pada kawasan wilayah tersebut.

Tidak adanya jargon Kampung Zombie pada kawasan kampung di daerah Kelurahan Mangkupalas, Samarinda Seberang, Kota Samarinda disebabkan karena Pemerintah Kota Samarinda memperbaiki citra/image kawasan kampung tersebut dengan mengubah jargon kawasan kampung tersebut menjadi jargon kawasan kampung yang cukup diminati oleh masyarakat.

Bukan hanya mengubah citra/image kawasan kampung tersebut, Pemerintah Kota Samarinda juga memperbaiki struktur kawasan kampung tersebut untuk menjadi salah satu destinasi favorit bagi parawisata Kota Samarinda, sehingga citra/image yang dulunya menjadi destinasi favorit bagi anak remaja sebagai tempat melakukan perilaku menyimpang inhalen (ngelem) telah berubah menjadi destinasi favorit bagi parawisata untuk masyarakat Kota Samarinda sebagai kawasan kampung yang telah diberi jargon kawasan Kampung Ketupat Warna Warni, Kelurahan Mangkupalas, Samarinda Seberang, Kota Samarinda.

Hal tersebut menurut pihak Kelurahan Mangkupalas Samarinda Seberang, Kota Samarinda, sebagai perwakilan Pemerintah Kota Samarinda merupakan bentuk upaya lainnya bagi meminimalisir pengguna inhalen (ngelem) aktif oleh anak remaja di kawasan kampung tersebut, sehingga kedepannya dengan hilangnya tempat favorit bagi anak remaja pengguna inhalen (ngelem) di kawasan kampung tersebut melalui perubahan citra image kawasan Kampung Zombie, Kelurahan Mangkupalas, Samarinda Seberang, Kota Samarinda menjadi kawasan Kampung Ketupat Warna Warni, Kelurahan Mangkupalas, Samarinda Seberang, Kota Samarinda, maka hilang juga tempat favorit, diharapkan mampu mengurangi perilaku inhalen (ngelem) pada anak remaja sebagai sebuah solusi yang diberikan oleh Pemerintah Kota Samarinda.

\section{B. Efektifitas Penegakan Hukum Terhadap Perilaku Ngelem Pada Anak Remaja Sebagai Pelaku Sekaligus Korban (Self Victimizing) di Kawasan Kampung Zombie Kota Samarinda}

Penggunaan Peraturan Daerah Provinsi Kalimantan Timur Nomor 05 Tahun 2015 Tentang Pencegahan Penyalahgunaan Inhalan sebagai alat penegakan hukum dalam menyelesaikan problematika fenomena sosial yang terjadi pada kawasan Kampung Zombie Kelurahan Mangkupalas, Samarinda Seberang, Kota Samarinda tersebut dirasa tidak berlebihan, namun juga belum dapat dinyatakan efektif dalam menangani perilaku inhalen (ngelem) pada anak remaja sebagai pengguna inhalen.

Berdasarkan observasi yang penulis lakukan, penegakan hukum dengan menjadikan Peraturan Daerah Provinsi Kalimantan Timur Nomor 05 Tahun 2015 Tentang Pencegahan Penyalahgunaan Inhalan sebagai dasar hukum, khususnya di kawasan Kampung Zombie Kelurahan Mangkupalas, Samarinda Seberang Kota Samarinda hanya mampu meminimalisir kuantitas anak remaja yang telah dinyatakan sebagai pengguna inhalen (ngelem) yang telah terjaring oleh aparat penegak hukum. Hal ini karena penegakan hukum terhadap perilaku menyimpang inhalan (ngelem) pada anak remaja berdasarkan ketentuan Peraturan Daerah Provinsi Kalimantan Timur Nomor 05 Tahun 2015 Tentang Pencegahan Penyalahgunaan Inhalan hanya bersifat, menunggu adanya laporan, pembinaan, dan pencegahan, sehingga sulit untuk dapat diserap oleh semua situasi terkait penegakan hukum terhadap perilaku inhalan (ngelem) pada anak remaja khususnya di kawasan Kampung Zombie Kelurahan Mangkupalas, Samarinda Seberang, Kota Samarinda.

Fakta yang menarik selama observasi, selain kawasan tersebut menjadi tempat favorit bagi anak remaja melakukan kegiatan inhalan (ngelem), pada kenyataannya sebagian besar anak remaja yang melakukan kegiatan inhalen (ngelem) tersebut tidak berasal atau tidak memiliki tempat tinggal di wilayah Kelurahan Mangkupalas, Samarinda Seberang, Kota 
Samarinda, dan hanya menjadikan kawasan tersebut sebagai markas mereka untuk melakukan kegiatan inhalen (ngelem), menjadi problematika penegakan hukum terhadap perilaku menyimpang inhalen (ngelem) pada anak remaja di kawasan tersebut.

Mengingat, kenyataan tersebut maka dapat bisa dipastikan penegakan hukum terhadap perilaku inhalen (ngelem) pada anak remaja sekaligus pelaku dan korban belum efektif secara keseluruhan, kenyataan bahwa anak remaja yang melakukan kegiatan inhalen (ngelem) tersebut bukan berasal atau tinggal di kawasan kampung terrsebut, tentu akan menyulitkan bagi aparat penegak hukum seperti pihak kepolisian, pihak Badan Narkotika Nasional (BNN), pihak kecamatan, dan kelurahan, dan pihak lainnya untuk dapat menertibkan perilaku menyimpang inhalen (ngelem), agar kawasan kampung tersebut dapat melepaskan jargon zombie yang melekat karena banyaknya anak remaja anak remaja pengguna inhalen (ngelem) di kawasan kampung tersebut.

Kompleksitas yang timbul terhadap penegakan hukum terhadap perilaku menyimpang penggunaan inhalen (ngelem) pada anak remaja membuat penegakan masih dirasakan setengah hati, belum lagi bila dilihat dari perspektif kedudukan anak remaja pengguna inhalen (ngelem) sebagai selfvictimizing. Bagaikan dua sisi mata uang yang penegakan hukumnya tidak dapat dipandang sebelah mata, tidak hanya dapat dilihat dari satu sisi pelaku (crime) atau dari satu sisi korban (victim), tapi harus dilihat dari kedua arah.

Selama ini penegakan hukum yang berdasarkan ketentuan Peraturan Daerah Provinsi Kalimantan Timur Nomor 05 Tahun 2015 Tentang Pencegahan Penyalahgunaan Inhalan terhadap anak remaja pengguna inhalen (ngelem) hanya dilihat dari satu sisi yaitu dari sisi korban (victim). Kecenderungan melihat anak remaja pengguna inhalen (ngelem) sebagai korban (victim) merupakan langkah yang dinilai tepat dan bijak dalam menangani fenomena sosial tersebut. Pertimbangannya bahwa anak remaja pengguna inhalen (ngelem) sebagian besar mengalami kerugian sehingga orientasinya lebih banyak mengarah sebagai korban daripada sebagai pelaku dalam perilaku menyimpang ini, Hal ini terjadi karena penegakan hukum yang dilakukan terhadap perilaku menyimpang penggunaan inhalen (ngelem) pada anak remaja belum mampu membuat fenomena sosial ini tidak ada lagi di tengah-tengah masyarakat. Masih ditemukannya anak remaja sebagai pengguna inhalen (ngelem) bukan hanya di kawasan Kampung Zombie Kelurahan Mangkupalas, Samarinda Seberang, Kota Samarinda saja, namun juga telah tersebar merata diseluruh Kota Samarinda yang belum terdata dengan baik dan terjaring oleh para aparat penegak hukum.

Kurang efektifnya Peraturan Daerah Provinsi Kalimantan Timur Nomor 05 Tahun 2015 Tentang Pencegahan Penyalahgunaan Inhalan yang menjadi landasan penegakan hukum terhadap anak remaja pengguna inhalen (ngelem) merupakan faktor penentu dikarenakan tidak adanya penegakan hukum terhadap anak remaja pengguna inhalen (ngelem) yang juga dilihat dari sisi pelaku (crime), sehingga menimbulkan ketidakakuratan yang disebabkan karena hilangnya rasa takut terhadap penindakan yang diberikan dan tidak ada efek jera bagi anak remaja pengguna inhalen (ngelem) yang melakukan perbuatan tersebut sampai berulang kali.

Ironinya, upaya lain yang diberikan oleh Pemerintah Kota Samarinda menurut penulis bukanlah solusi yang tepat dalam meminimalisir kuantitas pengguna inhalen (ngelem) pada anak remaja. Dengan melakukan perubahan citra/image atau perubahan jargon terhadap kawasan Kampung Zombie, Kelurahan Mangkupalas Samarinda Seberang Kota Samarinda menjadi kawasan Kampung Warna Warni bukan merupakan suatu tindakan efektif yang diharapkan dalam menyelesaikan problematika fenomena sosial tersebut.

Kurang efektifnya upaya ini dikarenakan hasil yang didapatkan dari perubahan citra/image dengan mengubah jargon kawasan kampung tersebut, hanya sebatas perubahan citra/image kawasan kampung agar menjadi lebih ramah dan menjadi salah satu destinasi wisata, namun sasaran utama untuk 
meminimalisir kuantitas pengguna inhalen (ngelem) pada anak remaja tidak tersampaikan. Perubahan citra/image kawasan kampung tersebut bertujuan agar anak remaja pengguna inhalen (ngelem) yang tidak tinggal di kawasan kampung tersebut tidak lagi menjadikan kawasan kampung tersebut sebagai markas untuk melakukan perilaku menyimpang penggunaan inhalen (ngelem), sehingga sifatnya berupa pengusiran atau pembersihan semata dari anak remaja yang menjadi pengguna inhalen (ngelem) agar kawasan tersebut mendapatkan citra/image yang lebih baik dan image Kampung Zombie tidak lagi melekat pada kawasan kampung tersebut. Efektifitas penegakan hukum yang harus dikejar bukan pengurangan angka melainkan membuat fenomena sosial tersebut tidak ada lagi.

Perubahan image menjadi kawasan Kampung Warna Warni, Kelurahan Mangkupalas, Samarinda Seberang, Kota Samarinda merupakan salah satu upaya pemerintah meminimalisir aktifitas penggunaan inhalen di kawasan tersebut, patut di apresisasi oleh masyarakat dan mampu mengurangi kuantitas di kawasan kampung tersebut. Akan tetapi apabila melihat efektifitasnya penegakan hukum yang dilakukan melalui pendampingan, advokasi sampai rehabilitasi serta perubahan image dirasakan belum dapat menekan atau bahkan menghilangkan perilaku meyimpang pada anak remaja di Kota Samarinda secara menyeluruh. Agar sebuah peraturan dapat berjalan efektif tetap membutuhkan dukungan masyarakat untuk dapat berperan aktif menjaga lingkungan tempat tinggalnya dari segala bentuk kegiatan menyimpang khususnya yang dilakukan oleh anak remaja. Sehingga kuantitas anak remaja pengguna inhalen (ngelem) yang ada di Kota Samarinda dapat semakin diminimalisir dan bahkan dihapuskan, karena tidak menutup kemungkinan ketika markas buat anak remaja pengguna inhalen (ngelem) hilang, dikhawatirkan kedepannya akan ada kawasan kampung yang dijadikan markas berikutnya dan kembali mendapatkan image serupa sebagai kawasan Kampung Zombie lainnya di Kota Samarinda.

\section{PENUTUP \\ KESIMPULAN DAN SARAN}

Berdasarkan hasil pembahasan mengenai "Efektifitas Penegakan Hukum Terhadap Perilaku "Ngelem" Pada Anak Remaja Sebagai Pelaku Sekaligus Korban (Self Victimizing) di Kawasan Kampung Zombie Kota Samarinda" maka dapat disimpulkan bahwa terdapat upaya-upaya penegakan hukum terhadap perilaku ngelem pada anak remaja sebagai pelaku sekaligus korban (self victimizing) dikawasan Kampung Zombie Kota Samarinda untuk mengurangi jumlah anak remaja pengguna inhalen, diantaranya berupa pencegahan, pembinaan dan pengawasan, advokasi, dan rehabilitasi, serta penindakan, sekaligus adanya perubahan image pada kawasan kampung tersebut.

Adanya upaya-upaya penegakan hukum terhadap perilaku ngelem pada anak remaja sebagai pelaku sekaligus korban (self victimizing) dikawasan Kampung Zombie Kota Samarinda tersebut dinilai belum dapat dinyatakan efektif, karena indikasi efektif yang harus dikejar bukan pengurangan angka atau perubahan image sebuah kampung melainkan membuat fenomena sosial tersebut tidak ada lagi. Perubahan image menjadi kawasan Kampung Warna Warni, Kelurahan Mangkupalas, Samarinda Seberang, Kota Samarinda merupakan salah satu upaya pemerintah meminimalisir aktifitas penggunaan inhalen di kawasan tersebut, patut di apresisasi oleh masyarakat dan mampu mengurangi kuantitas di kawasan kampung tersebut. Akan tetapi apabila melihat efektifitasnya penegakan hukum yang dilakukan melalui pendampingan, advokasi sampai rehabilitasi serta perubahan image dirasakan belum dapat menekan atau bahkan menghilangkan perilaku meyimpang pada anak remaja di Kota Samarinda secara menyeluruh.

Oleh karenanya penulis memiliki saran yaitu sebaiknya dalam rangka mewujudkan kepastian hukum, dan keadilan hukum diperlukan adanya koordinasi antar instansi terkait yang saling besinergi untuk berkomitmen memperbaiki ketimpangan sosial yang disebabkan perilaku menyimpang di masyarakat termasuk perilaku ngelem pada anak remaja yang tidak hanya dilihat dari satu 
sisi melainkan dari dua sisi baik dari sisi pelaku (crime) maupun dari sisi korban (victim) sehingga ada efek jera yang mampu menekan kuantitas anak remaja pengguna inhalen (ngelem) secara menyeluruh di wilayah Kota Samarinda.

Selain itu juga diharapkan kedepannya tercipta suatu intensitas dalam hal pembinaan, dan pencegahan sehingga sifatnya bukan hanya menunggu apabila ada laporan, akan tetapi pemerintah lebih aktif dan memperbanyak penindakan dalam bentuk razia di beberapa daerah yang terindikasi bekerjasama dengan lembaga swadaya dan masyarakat sebagai bentuk upaya penegakan hukum dalam menyikapi fenomena sosial tersebut.

\section{UCAPAN TERIMA KASIH}

Penelitian ini merupakan Penelitian Dosen Pemula DIKTI, jangka waktu penelitian selama 1 tahun, dengan Nomor Kontrak:

514/KONTRAKPENELITIAN/K11/KM/2018, tanggal 22 Februari 2018. Oleh karena itu, Penulis ingin mengucapkan Terima Kasih sebesarnya kepada Kementrian Riset dan Teknologi Pendidikan Tinggi atas perkenan menerima hasil penelitian dosen pemula ini.

Buku :

\section{DAFTAR PUSTAKA}

Atmasasmita Romli, 1992, Teori dan Kapita Selekta Kriminologi, Bandung: Eresco 1993, Penulisan Karya Ilmiah Tentang Masalah Santunan Terhadap Korban Tindak Pidana, Badan Pembinaan Hukum Nasional Departemen Kehakiman RI, Jakarta.

Muladi, 1997, Hak Asasi Manusia, Politik dan Sistem Peradilan Pidana, Badan Penerbit Universitas Diponegoro, Semarang.

Gosita Arif, 1993, Masalah Korban Kejahatan . Akademika Pressindo. Jakarta.

Ihyaul MD Ulum, 2004, Akuntansi Sektor Publik, Malang,UMM Press

Makarao Taufik, Tindak Pidana Narkotika . Ghalia Indonesia . Jakarta: 2005.

M. Richard, Steers, 1985, Efektivitas Organisasi, Jakarta, Erlangga.

Narwoko Dwi, dkk. 2004. Sosiologi Teks Pengantar dan Terapan Edisi ke Empat. Jakarta: Kencana.

Shant Dellyana,.1988. Konsep Penegakan Hukum. Yogyakarta: Liberty.

Soekanto Soerjono. 2004. Faktor-Faktor Yang Mempengaruhi Penegeakan Hukum Cetakan Kelima.Jakarta : Raja Grafindo Persada.

Yulia Rena, 2010, Viktimologi Perlindungan Hukum Terhadap Korban Kejahatan, Graha Ilmu, Yogyakarta. 


\section{Perundang-Undangan :}

Undang-Undang Dasar Tahun 1945 Amandemen ke IV.

Undang-Undang Nomor 11 Tahun 2009 tentang Kesehjateraan Sosial.

Peraturan Pemerintah Nomor 25 Tahun 2011 tentang Pelaksanaan Wajib Lapor Pecandu Narkotika.

Keputusan Presiden Republik Indonesia Nomor 11 Tahun 2016 Tentang Program Penyusunan.

Peraturan Presiden Tahun 2016 mengenai Rancangan Peraturan Presiden tentang Optimalisasi Penanggulangan Penyalahgunaan Narkotika

Peraturan Daerah Provinsi Kalimantan Timur Nomor 05 Tahun 2015 tentang Pencegahan Penyalahgunaan Inhalen.

\section{Media Cetak}

- $\quad$ Tribun Kaltim.

- Radar Kaltim.

- $\quad$ Samarinda Post.

\section{Media Internet}

Anonim,http://eournal.uajy.ac.id/4241/3/2MH 01723.pdf.

www.wikipedia.com

www.google.com 